\title{
Attention to Disruption and Blockchain Creates a Viable Real Estate Economy
}

\author{
Jan Veuger \\ Hanze University of Applied Sciences Groningen, Groningen, the Netherlands
}

\begin{abstract}
Does real estate still have the value that it once had, or will the valuation of real estate change due to surprising products and services, innovative business models, different market strategies, innovative ways of organizing and managing in the (real estate) markets? Innovation revolves around good facilities in an attractive and stimulating environment. Take disruptive real estate for example. The driving forces behind these developments are new technology, viability, organizing differently, and managing, and these have a big impact on the valuation of real estate. Established names like Nokia, Kodak, Blockbuster, Oad, Free Record Shop, Hyves, and V\&D collapse, and others, like Hema, Shell, hotel chains, and healthcare institutions are the least bothered by it. However, disruptive organizations like Amazon, Zalando, Uber, Tesla, and its competitor Faraday Future who wants to exceed Tesla in everything, clearly respond to viability in the environment, and this is determinative for competitive strength and thus impacts the current and future valuation of real estate. Blockchain - a distributed database that contains a growing list of data items and that is hardened against manipulation and counterfeiting — plays an important role in that. The notaries and brokers have already experienced this in the recent period, and it will continue to have an effect on real estate owners, financiers, users, builders, brokers, notaries, and the cadastre. The real estate world finds itself at a tipping point of a transition: a dramatic and irreversible shift in (real estate) systems in society. This paper is a state of the art of disruption, Blockchain, and real estate in the Netherlands and international world.
\end{abstract}

Keywords: disruption, real estate, Blockchain, trust, value

Does real estate still have the value that it had, or is the valuation of real estate going to change due to surprising products and services, innovative business models, other market strategies, innovative ways of organizing and managing in (real estate) markets? Innovation revolves around good facilities in an attractive and stimulating environment. Take disruptive real estate for example. The driving forces behind these developments are new technology, manoeuvrability, organizing differently, and management. These forces greatly influence the valuation of real estate. Established names like Nokia, Kodak, Blockbuster, Oad, Free Record Shop, Hyves, and V\&D are collapsing, and, for example, Hema, Shell, hotel chains, and healthcare institutions are the least affected. Disruptive organizations like Amazon, Zalando, Uber, and Facebook, who are going to develop a complete residential area in California, Tesla and its competitor Faraday Future, who wants

Corresponding author: Jan Veuger, MRE, Ph.D., FRICS, professor of Real Estate at the Research Centre for Built Environment NoorderRuimteat, Hanze University of Applied Sciences Groningen, Groningen, the Netherlands; research fields: practice-oriented research into the built environment in the Northern Netherlands, earthquakes, shrinkage, sustainability \& abundance, and health \& wellbeing, improved (re)design of the built environment for people, architecture, architecture \& civil engineering, real estate $\&$ brokerage, industrial product design and facility. 
to surpass Tesla in everything, respond to viability in the environment. This viability determines the competitiveness and thus affects current and future valuation of real estate. Blockchain, a distributed database that maintains a growing list of data items and that is hardened against manipulation and counterfeiting, plays an important role in that. Notaries and brokers have already encountered this during the recent period, and it will have further impact on property owners, financiers, users, builders, brokers, notaries, and the land registry. The real estate world is therefore at a turning point of transition: a profound and irreversible tilting of (real estate) systems in society, and "technological opportunities that we can hardly anticipate" (Dijkgraaf, 2017). The International Monetary Fund (IMF) also acknowledged the major possible consequences of changes in our financial and thus real estate system and held a meeting at the highest level in April 2017 about Blockchain, chaired by Christine Lagarde ${ }^{1}$.

Viability determines competitiveness strength and generally has four building ${ }^{2}$ blocks for its development: (1) looking outward (external focus); (2) following good examples closely (connecting leadership); (3) self-organizing units (flexible work organization); and (4) modelling and generating (flexible processes and IT). To develop that viability, a number of competencies are ${ }^{3}$ important, such as continuous insight into customer behaviour, process-oriented steering, dynamic skills, strategic alliances and networks, and meaningfulness. Disruption is usually associated with the development and application of new technology by organizations. Characteristics of these organizations are often a small headquarters, few staff, own results responsibilities, autonomy of the various parts and professionals, and flexibility of staff upon request. Fundamental changes in the market in housing, work, education, healthcare, and transport will therefore affect real estate, as well as technology in buildings. But which real estate fits these new developments of disruption, and what is Blockchain's impact on real estate? First of all, we consider how disruption works.

\section{What Is Disruptive Real Estate}

Disruption $^{4}$ is a predictable pattern in all sectors where start-ups use new technology (Vermeend \& Smit, 2017) to make it possible for "something new and small" to penetrate "something existing and big" in a short space of time. At the moment, many start-ups are disturbing different sectors by competing with the established representatives. But how does disruption work? Former Microsoft executive Steven ${ }^{5}$ Sinofsky gives an answer through a framework he designed (see Figure 1) in which he distinguishes four phases of disruption: disruption, evolution, convergence, and re-imagination.

The four phases - disruption, evolution, convergence, and re-imagination of disruption are specified in Table 1 below. On the right, we see the established order (incumbent); on the left, we see the challenger (disruptor) who grows from a niche solution to an advantage for everyone.

The renowned magazine The Economist $t^{6}$ praised the "disruptive innovation" theory of Clayton Christensen as "one of the most influential modern business ideas" ever. The theory has been repeatedly used to explain the

\footnotetext{
1 Source: http://www.coindesk.com/imf-just-finished-first-high-level-meeting-Blockchain/.

2 Source: https://www.managementsite.nl/wendbaarheid-strategie-concurrentiekracht.

3 Source: https://www.managementsite.nl/competenties-wendbare-organisatie.

4 Source: https://www.emerce.nl/achtergrond/hoe-werkt-disruptie.

5 Steven Sinofsky (1965) was the president of the Windows and Windows Live division for Microsoft between September 2008 and November 2012, and in that capacity responsible for the development and marketing of Windows, Windows Live, and Internet Explorer. Sinofsky was the great promoter of the "Ribbon" interface, and the driving force behind the development of Windows 8

${ }^{6}$ Source: http://www.marketingfacts.nl/berichten/bestaat-er-wel-zoiets-als-een-theorie-over-disruptie.
} 
success of companies like Netflix, Spotify, Uber, Airbnb, Faraday Future, and Tesla. Disruption is the new religion preached from Silicon Valley. However, the question is how much value we should attach to this faith?

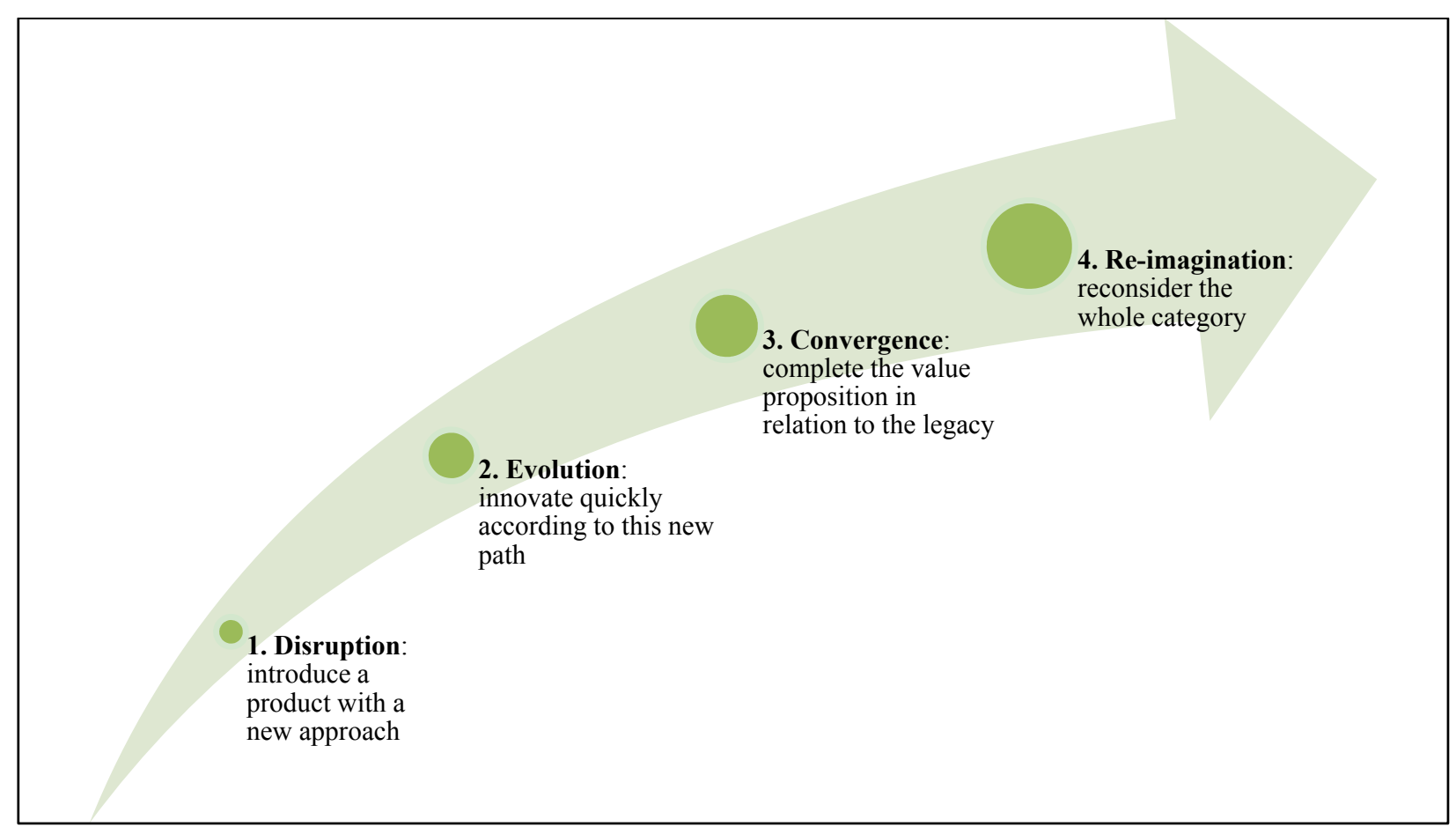

Figure 1. The four phases of disruption of Steven Sinofsky (editing by Veuger, 2017).

Table 1

The Four Phases of Disruption Specified ${ }^{7}$

\begin{tabular}{|l|l|l|}
\hline Phase & Challenger (disruptor) & Incumbent [established order (incumbent)] \\
\hline $\begin{array}{l}\text { Disruption of established } \\
\text { order }\end{array}$ & $\begin{array}{l}\text { Introduces a new product with a distinctive } \\
\text { approach, knowing that it does not meet all the } \\
\text { needs of the entire existing market but is an } \\
\text { improvement of state-of-the-art technology } \\
\text { and/or business. }\end{array}$ & $\begin{array}{l}\text { The new product or new service is not relevant to } \\
\text { existing customers or markets (also known as } \\
\text { "denying"). }\end{array}$ \\
\hline Rapid linear evolution & $\begin{array}{l}\text { Quickly adds features and capabilities, thus } \\
\text { building up the value proposition based on the } \\
\text { responses of a select company of early adopters. }\end{array}$ & $\begin{array}{l}\text { Compares the complete product with its own new } \\
\text { "validation"). }\end{array}$ \\
\hline Attractive convergence & $\begin{array}{l}\text { Sees an opportunity to broaden the customer base } \\
\text { by attracting slow movers. Also sees the } \\
\text { limitations of the new product and learns from } \\
\text { what has been done in the past, but applied in a } \\
\text { new way. Potential risk is constantly being } \\
\text { addressed with even newer technology and } \\
\text { business models, while the focus shifts to the } \\
\text { "installed base" of the established order. }\end{array}$ & $\begin{array}{l}\text { Considers adding a certain disruptive core feature } \\
\text { is paid to future trends while at the same time } \\
\text { interfering with existing customers (also known } \\
\text { as "competing"). One possible risk is that you } \\
\text { cannot see what the true value of disruptive } \\
\text { products is or what the potential is in relation to } \\
\text { the limitations of existing products. }\end{array}$ \\
\hline $\begin{array}{l}\text { Completely new invented } \\
\text { product }\end{array}$ & $\begin{array}{l}\text { Approaches a decision point because newcomers } \\
\text { in the market can take advantage of everything } \\
\text { that your product has demonstrated without } \\
\text { taking into consideration the old customers like } \\
\text { before. Do you focus more on the legacy of the } \\
\text { market or do you continue on this path? }\end{array}$ & $\begin{array}{l}\text { Is too late to respond and begins to define the } \\
\text { new product as part of a new market and existing } \\
\text { product as part of a larger, existing market (also } \\
\text { known as "withdrawal"). }\end{array}$ \\
\hline
\end{tabular}

${ }^{7}$ Source: http://recode.net/2014/01/06/the-four-stages-of-disruption-2/. 
The first publication of the basis of the theory of disruptive innovation is by Clayton M. Christensen, dating back to 1995 (Christensen \& Bower, 1995) when the Internet was barely existent. According to him, for example, Uber and WhatsApp are not typical disruptive innovations. According to him, it is just a simpler product for a target group with little money and lower expectations. Examples of those products are the smartphone with ever-new apps that displace the personal computer, or Bitcoin replacing current payment traffic. A newcomer is therefore in the optics of Christensen much more successful than innovations that make an existing market because this market would respond directly to external innovations. So one disruption is not like another. Disruption is a predictable pattern in sectors where emerging companies use new technology to provide cheaper and inferior alternatives to products of established players in the market. An example of this is Toyota, which took on the battle with Detroit a few decades ago.

Disruption matters and brings about physical changes. Google in Silicon Valley evolved there where people are physically brought together in buildings that are primarily aimed at exchanging knowledge and stimulating creative processes. Behaviour that shakes loose new technology leads to new business models: the social spin-off is at the heart of the revolution (Bakker, 2017). The true revolution often takes place in everyday practice. An investment like the Google data centre Groningen is a result of a convergence of things. Groningen has been chosen precisely because of the availability of energy, good infrastructure, the Dutch climate, and the point where the fibre-optic connection between the United States and Europe passes by and thereby forms a global network. Innovation and productivity are also strongly promoted by high population densities and masses, fast transportation systems, and highly specialized universities such as the UMC (University Medical Center) Groningen with its new Proton Therapy Centre, the State University of Groningen, and the Hanze University of Applied Sciences Groningen with its knowledge centres. Imagining if you are evaluated as an organization based on, for example (Sfirtsis \& Broekman, 2016):

(1) The number of visitors per quarter in a retail chain;

(2) The contribution of an office concept to employee satisfaction;

(3) The flexibility of a shopping concept based on seasons and lifestyles;

(4) The amount of time a property is rented by a user;

(5) Effectively bringing together all the necessary parties (including the end user) to achieve the ultimate customer experience.

Then the (real estate) world looks different, if the user is really leading. Healthcare, for example, is also organized in a different way as a result of more new treatment methods than we have developed so far. Examples of these new methods of treatment include haemodialysis (kidney dialysis), monitoring high-risk pregnancies, chemotherapy (Erasmus Hospital), infusion therapies, and palliative intensive care (Westfries Hospitals and Medical Spectrum Twente).

The foregoing examples indicate that these issues will affect current and future real estate with themes such as: (1) clear, distinctive value propositions; (2) price erosion, different margins, and price competition; (3) valuation in the short and long term; (4) overcapacity; (5) demand changing faster than supply; and (6) power imbalance in the real estate (value) chain.

The disruptive changes in the real estate world, as we know it, will even further strengthen and demand different real estate. Buildings that do not take into account the rapid changes are less viable. Organizations that use real estate as a business asset and take lessons learned from the Corporate Real Estate Management field to heart are more viable (Veuger, 2014, p. 132). Real estate must be adaptable, disrupting, in a good location, 
sustainable, and distinctive. And it must be all of that in a context where the spatial and built environment stimulates innovation and promotes knowledge sharing and cooperation. Within the city of Groningen and beyond, the surrounding areas demand a well-functioning network to make spatial connections and share facilities. At the national and international level, concentration of highly specialized developments and top research institutes is needed. Innovation revolves around more than excellent facilities in an attractive and stimulating environment. Take disruptive real estate for example. If real estate can be disruptive, what relationship is there with Blockchain? When we want to understand the world of Blockchain, we need to understand the innovation of the currency of Bitcoin, which is based on the underlying technology called Blockchain.

\section{The Relationship Between Blockchain and Bitcoin}

Blockchain could have a huge impact on the value chain in real estate. This includes thinking about efficiency, transparency, ownership, value (transfer), automation, and service. If we want to understand the world of Blockchain, we need to understand the innovation of the currency of Bitcoin, which is based on the underlying technology (Seibold \& Samman, 2016) called Blockchain. Bitcoin is a combination of four individual elements: (1) cryptography; (2) a peer-to-peer network; (3) an open-source protocol; and (4) a shared ledger. This makes it a phenomenon that people are enthusiastic about. The applied cryptography (first element) is complex, but comparable with banks, which use it to secure their transaction traffic. The peer-to-peer network (second element) we already know from the exchange of music exchange. The essence of this is that a network of parties, called miners, validates the transaction register worldwide. This means that there is no exclusive right to that network, and it is not possible to turn a particular location on or off. The network is connected with the third element, with which the underlying software is fully public: an open-source protocol. This allows everyone to see how the software is programmed. All of this is unique in that Bitcoin is already an alternative of money on the Internet, and it is growing very fast. To illustrate: on January 1, 2017, the Bitcoin rate went through the $\$ 1,000$-dollar limit (953 euros). The most striking thing about Bitcoin is that value is transferred without involving a trusted third party such as a bank, notary, broker, or cadastre. That is unprecedentedly relative to the current financial and real estate world with a third party as a safe agency between the buying and selling party. But is Bitcoin the future? No, according to Blockchain expert Dennis de Vries ${ }^{8}$, it is not, but the underlying Blockchain technology is.

The Internet makes it possible to transfer information quickly, cheaply, and paperlessly without the need for any intermediaries. Blockchain gives the same benefits for transferring values. The Internet is used to transfer word and image; Blockchain, for money and asset transactions. Blockchain is a combination of two elements: (1) a shared and distributed ledger with synchronized data spread across multiple sites, countries, and/or institutions; and (2) cryptography: a digital token with a monetary value. Blockchain has a number of benefits in realizing real estate transactions: preventive mediation, fraud prevention, and the use of smart contracts. But what is the meaning of Blockchain for the real estate sector?

\section{Blockchain and the Real Estate Sector}

The financial sector has become excited about how Bitcoin has programmed the value transfer and how the transactions are processed without having a third party, such as the government or bank, part of a transaction. All banks worldwide have their own IT systems that are complicated, communicate inefficiently, and let transactions

${ }^{8}$ Source: http://innovators.kpmg.nl/nl/blogs/the-Blockchain-promise/. 
take place. There is a realization that this can be much simpler with a customized open-source protocol. And why would that not apply for real estate? An important discussion about this theme also concerns the cadastre, with the registering of property ownership. Blockchain can be a more efficient way of registration in order to transfer ownership. However, the critical footnote should be placed here that real estate also exists in the real world in trading with Blockchain. There will have to be a clear connection between the administration in Blockchain and the physical property. At this time, this connection is not (yet) scientifically proven. What we see is that heavy investments are being made in, for example, a new global registration system on the basis of Blockchain and that established parties see opportunities to make processes simpler and to develop more user-friendly systems.

Key advantage of Blockchain is that changes can no longer be made once a block has been added. This means that errors must always be corrected before a transaction can be done. Adjustments always remain visible in Blockchain, thus keeping the registry transparent and providing the basis for trust in the system. This allows, for example, duplicate expenses to be avoided and no shadow transactions can occur.

With the help of Blockchain, we can bring together all information about buildings and give access to parties who need the information. It then works as a kind of building passport (see Figure 2). Thus, a data room is created in which different information from buildings is stored. Any interested party can add information from, for example, tenants, valuations, history, and maintenance plans. Banks can also check the financing more easily and monitor, for example, cash flow. According to Yermack (2017), professor and expert on Blockchain, the work now done by auditors will disappear. With the Building Information Model (BIM), data will also exchange information about design and materials use that can contribute to a circular economy. Demolition of a building and responsibilities for installation technology become more transparent and clearer with BIM. With a change of ownership, it is also very easy to change the complete building passport. Other examples of application areas include title registration, service costs, real estate as a service, building maintenance, settlements of various forms of taxation, real estate valuations such as the Wet Onroerende Zaken (WOZ, Law Real Estate), refurbishment value for insurers, and records of an Association of Owners ( $\mathrm{VvE}$-Vereniging van Eigenaren).

Gebouw paspoort

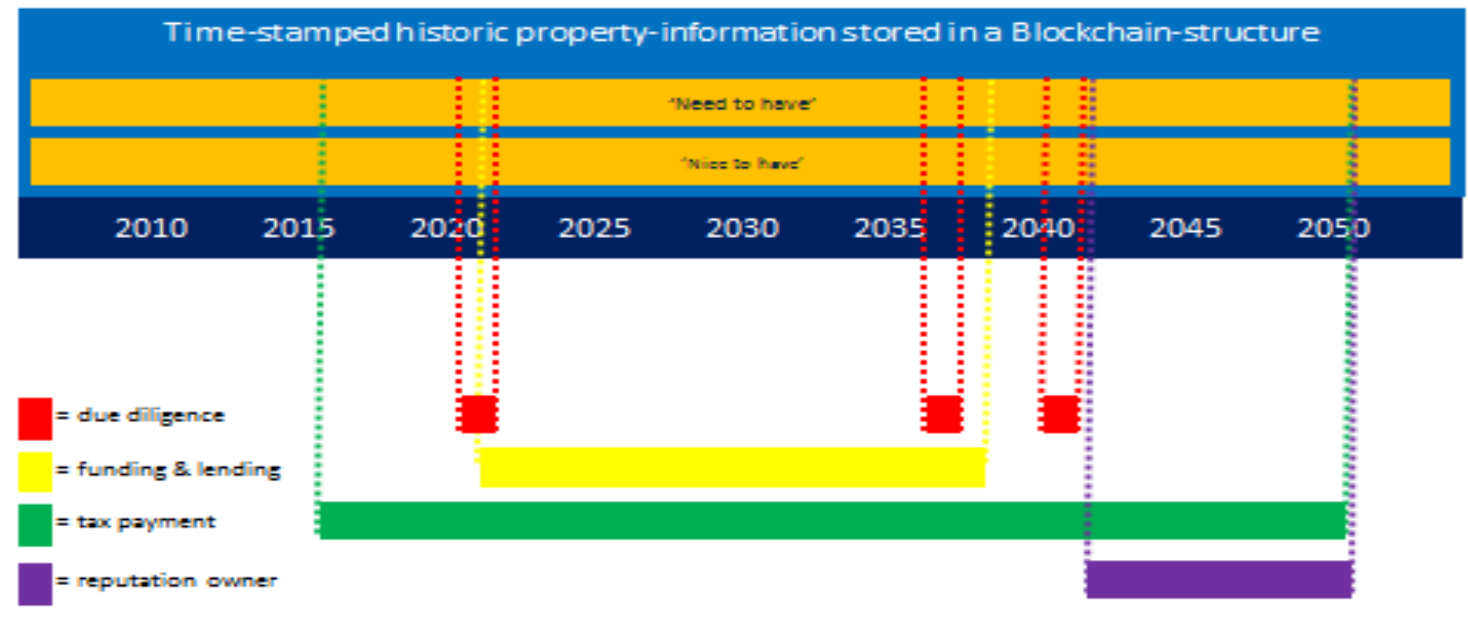

IBREA

Figure 2. Building passport: Time-stamped historical ownership information stored in a Blockchain structure (source: Bronckers, 2017). 


\section{Two Changes}

The real estate sector will also face two fundamental changes: (1) the use of the Blockchain in the real estate sector itself; and (2) the broad social impact as a result of the users of real estate. A first major change through the application of the Blockchain is in the registration and processes of real estate titles, due diligence processes, simplification of currently complex transactions, faster turnaround times of transactions, and more liquidity (Wessels, 2016). Blockchain's technology allows contracts to be smart and can therefore be executed under predetermined conditions. Real estate finance can also be further automated with Blockchain, or it can contribute to the simplification of crowd funding. The big advantage of these movements is that the real estate market will become more transparent, the quality of (real estate) data will increase, and fraud prevention becomes more effective. The second major change is the social impact as a result of designating the users of real estate. If we draw a comparison with the developments with the Internet and its impact - see the social impact of smartphones - new patterns of users or real estate will change significantly. Existing institutions will disappear or change significantly, and other parties will rise.

\section{Disruption in Full Swing ${ }^{9}$}

Wensing, Director of Investment Management at Amvest, outlines how disruption is in progress. The traditional model for all sectors is under pressure. Innovations are necessary and offer opportunities. As a real estate company, you must make a connection between technology and other megatrends through structured preparation and approach. Amvest recently won the tender together with Synchroon for a 350-dwelling residential building at the Koningin Julianaplein in The Hague. What is unique about this project is that for the first time such a building is being developed on this scale without parking for residents. The young target group has much less need for a car. Amvest is going to invest in facilities to enable auto sharing. Wensing also sees major developments looking at likes on Facebook of housing offerings. For example, we are already ready in the housing market for a "Funda II", where the property manager can link his offer much better. "There is hardly any real estate agency involved for our new construction projects". Wensing also predicts a great future for domotics, the use of electronics for the automation of processes in and around the home (Wessels, 2016).

Van Rhijn, partner and chief executive officer of Colliers International Netherlands, points out that real estate seems to be lagging behind other markets. Colliers International wants to change that and sees different possibilities. In 2009/2010, Boer Hartog Hooft joined Colliers International, partly because of the insight that it is time to say goodbye to the activities in housing brokerage and to look for activities that had higher added value. Van Rhijn predicted, among other things, that as a result of digitization and social media, the office market will increasingly resemble the hotel market, where liking and reviewing have become a matter of course. "It is even true that reviews and likes for the hotel market are a better basis for determining the value of a building. That will also become very important for the office market" (Wessels, 2016).

Now that we have a picture of what Blockchain may mean for the real estate sector, we consider Blockchain's developments in real estate at the international, national, and regional level.

\section{Developments of Blockchain}

TopTeam ICT has taken the initiative to establish the Blockchain Competence Centre (BC3), in which scientists, governments, and social and industrial partners are working on building Blockchain expertise in the

9 Text of Wensing and van Rhijn: Wessels, 2016. 
Netherlands. BC3 thus meets the concerns expressed by the financial market about the lack of Blockchain expertise in the Netherlands. René Penning de Vries has been appointed by the Ministry of Economic Affairs as the standard bearer for TopTeam ICT ${ }^{10}$.

Blockchain has the advantages of being more efficient, more transparent, faster, and safer. But when can we expect Blockchain in the Netherlands? According to Jo Bronckers, chair of the International Blockchain Real Estate Association (IBREA) and the international trade association promoting the application of Blockchain in the real estate sector:

I think we are at the start of this technological change. The first step was to build a network infrastructure that allows data to be exchanged. The real estate world also sees added value in this and is investing in getting more and better data. For example, an initiative such as the Real Estate Taxonomy, streamlines the standardization and digitization of real estate data to improve the interchangeability of real estate data between banks, investors, and valuers. (Real Estate Journal, 2017)

There are a number of movements to be distinguished at the international, national, and regional level.

\section{Internationally}

According to Jo Bronckers, chair of IBREA, the Netherlands should be the forerunner in Blockchain technology. It is expected that the disruptive power of Blockchain's technology will increase worldwide (KPMG, 2016). For example, in Dubai, there are already plans to have all government documents in Blockchain by 2020 . Singapore is also accelerating developments in this area. Both cities are comparable to the Netherlands because the administrative layers are well-connected and the distances between the authorities are short. In addition, the Netherlands has a good digital infrastructure, a highly educated population, and the Dutch easily adapt to circumstances. In addition to the fact that the Dutch government has adapted Blockchain, several pilots have also been launched in the real estate area in the Netherlands. Through this move, the possibilities for the real estate world can be explored and transformed into global entrepreneurship of and with real estate. Bronckers states: "I see through the IBREA network what is happening worldwide, and I dare to say sincerely that we now have very good opportunities in the Netherlands to make this disruption work to our advantage". In 2016, the research of Spielman (2016) of the Massachusetts Institute of Technology (MIT) — one of the most prestigious technical universities in the world-appeared. This exploratory study into "recording property titles" compares the benefits and limitations of Blockchain with the current system of registration in Nashville (Davidson County), Tennessee. Following this thesis, they also launched an actual pilot project.

\section{Nationally}

The Netherlands also has ambitions for working with Blockchain. This is evidenced by presenting an action agenda with the National Blockchain Coalition (Dutch Blockchain Coalition, 2017) with three objectives:

(1) Developing Blockchain building blocks, such as digital identities.

The first step is to develop so-called digital identities that enable individuals, objects, and legal entities to perform digital transactions as part of a Blockchain.

(2) The realization of the conditions for utilizing Blockchain.

Working on solutions in the area of legislation and acceptance.

(3) Developing and realizing the Human Capital Agenda.

${ }^{10}$ Source: https://fd.nl/Print/krant/Rubriek/Opinie/1179845/opbouw-van-kennis-Blockchain-in-nederland-is-in-de-maak. 
For knowledge development, agreements are made about training, sharing knowledge, and increasing skills, i.e. investing in human capital.

The founding partners of the National Blockchain Coalition are expecting Blockchain and digital trust to greatly affect financial services, logistics, energy supply and, eventually, healthcare. They mainly see positive effects on the autonomy of citizens, transparency of transactions, cyber security, and reduction of administrative burdens. The participating parties in the coalition are: ABN AMRO, ING, Volksbank, Rabobank, PWC, Nationale Nederlanden, Havenbedrijf Rotterdam, Enexis, Alliander, the Koninklijke Notariële Beroepsorganisatie, Brightlands, the Ministries of Economic Affairs, Infrastructure and Environment, Security and Justice, Domestic Affairs and Royal Relations, the Delft University of Technology (TU Delft), Tilburg University, Radboud University, TNO (Netherlands Organisation for Applied Scientific Research), RDW, Rijksdienst voor Identiteitsgegevens, the Netherlands Organisation for Scientific Research, Kamer van Koophandel, Inspectie Leefomgeving en Transport, and the CWI (Centrum Wiskunde \& Informatica). The social perspective is introduced by ECP (Platform for the Information Society). Supporting organizations are: Financial Markets Authority, Betaalvereniging Nederland, De Nederlandsche Bank, DutchChain, Dutch Association of Banks, SIVI, StartupDelta, and the Dutch Association of Insurers.

Pouwelse is currently leading the Delft Blockchain lab and is the founder of Tribler, the research team at TU Delft. The Tribler team is the world's largest experimental research team working on self-organizing Internet systems. The team focuses on defining an attack-resilient and legally valid social media infrastructure. "We are still the only player with working technology in this area. We are running hard to go live this year" (Pouwelse, 2017). The prototype developed under the leadership of Pouwelse is provided with software terminals that enable other stakeholders to work on services around the Blockchain mortgage process. Examples of this are a service that bundles money offers to contracts that cover a mortgage application or market transparency facilitation services and static information about the online mortgage market (Zaal, 2017). Pouwelse says: "TU Delft is not going to be a mortgage lender, but we have made the technology that could trigger an online ecosystem of start-ups in and around financial services". The ABN AMRO Bank is responding positively to TU Delft's initiative. "The collaboration and technology brings us insights into how the future with Blockchain can look, what the role of financial institutions is therein and what value we can offer to our customer as a bank", explains Head of Innovation Centre Arjan van Os (Zaal, 2017). ABN AMRO, in collaboration with IBM, has also launched a Blockchain experiment (Bikker, 2016), bringing together information related to the building. Due to Blockchain's "single source of truth", banks are also convinced that through smarter contractual opportunities, the real estate industry is going to change significantly. Among other things, work is being done on so-called "proof of concepts" to investigate how Blockchain can eliminate uncertainty about collateral taxation (van Os, 2016). In addition to the research of Gout (2017) about one block-mortgage, a Blockchain-inspired business model for mortgage financing, Dijkstra (2017) conducted exploratory research into the real estate management process of sales and management. His research will reveal the potential opportunities that lie for applying Blockchain in real estate processes and where this needs to be further elaborated.

The Municipality of Rotterdam, Cambridge Innovation Centre (CIC) Rotterdam, and Deloitte have been working together since the beginning of 2017 to develop the first Blockchain application in real estate for the purpose of documenting rental contracts. As a result, start-ups can, for example, close rental contracts faster and easier. By documenting these rental contracts from the CIC network on the Blockchain, we can work more 
efficiently and management happens in a transparent manner. The next step in this project is to monitor rent payments. The project also includes the development and execution of pilots as part of the Roadmap Next Economy - a roadmap for the coming 10 to 20 years, with scenarios and trade perspectives - for 23 municipalities in the Metropolitan Region of Rotterdam-The Hague. The Roadmap aims to determine the impact of potentially disruptive technology like Blockchain by experimenting with it in the early stages. Within the project, five important steps have been taken:

(1) Digitalizing building data: creating a Blockchain ledger with real estate information for any building that can be converted and registered on Blockchain;

(2) Digitalizing the ownership situation: linking the registration to the owner. The cadastre and the Kamer van Koophandel are now playing a further role in this;

(3) Transferring ownership: the holder of registration is the sole entitled party who can encumber the registration with obligations such as a rental contract;

(4) Closing of rental contracts: multiple parties can work on signing the rental contract in the registration;

(5) Unlocking contract information for third parties: during the life cycle, the property owner will share information with third parties, such as for (re)financing. With such changes, checks are performed on currency and completeness.

Two important reactions emerged during the presentation of the research results on 18 May, 2017. Firstly: during the explanation of the developed platform, the responses were gauged among the attendees. The $60 \%$ of them want to apply or are already applying Blockchain. The $98 \%$ are convinced that Blockchain will affect the real estate market. Only the $4 \%$ think that there is too much transparency due to Blockchain. These results show confidence in Blockchain and that parties in the real estate sector want to get started. And secondly: the human factor is seen as the biggest obstacle to the actual application of the Blockchain. Blockchain is a disruptive innovation, potentially changing the current roles and tasks of players within the real estate market. In this sense, it is about more than just a technological innovation. Organizational change and adaptation of processes, work and methods, as a result of the technological capabilities that Blockchain will offer, are expected to be a challenge.

\section{Regionally}

In February 2017, Groningen was the epicentre of the newest Internet technology with the Blockchain Hackathon 2017 in The Big Building in Groningen. The purpose of this and further hackathons is to share knowledge, find solutions, and further develop, connect, strengthen, and accelerate the system through collaboration and creating opportunities for all stakeholders. The 400 participants, 55 teams from 11 countries laid the foundation for Blockchain applications. This is the world's largest Blockchain hackathon so far. Themes were international negotiation and enterprise, future retirement chain, energy transition, digital identity, and public services. Several organizations attached their names to the hackathon: Kamer van Koophandel, APG, PGGM, ICTU, Energy Academy Europe, Nuon/Vattenfall, and the N.V. Nederlandse Gasunie.

Furthermore, at the regional level, Blockchain mainly finds applications in the form of collaborations of administrations of (semi-)governments. An example of this has been the Stadjerspas.nl over the last year. This gives residents of the Municipality of Groningen a low-income discount on activities and products such as museum visits, membership of the library and sports associations. In Groningen, the number of users increased from 5,000 in the first quarter of 2016 to 15,000 with 3,000 transactions per month (Zuidam, 2016) in May 2017. 
Many large municipalities are working on such constructions. Policy makers also want to make more use of vouchers for energy with Blockchain's transaction infrastructure. A further application for (regional) real estate is not expected immediately, but could easily follow the above-mentioned developments.

In the summer of 2017, Bloqhouse launched a pilot in Amsterdam whose results are not yet public. Bloqhouse users can invest from 10 euros in buying shares and thereby become part owners of real estate. They are thus entitled to part of the rental income and the value development. The question is how this will further develop in the coming period.

The Investment and Development Agency for the Northern Netherlands (NOM) is working on 10 pilot projects on various ICT developments and working closely with various companies and knowledge institutions to further develop new technologies. Examples of these collaborations are in the field of energy with the N.V. Nederlandse Gasunie, public service with DUO, Hanze University of Applied Sciences Groningen and RDW, and in the area of healthcare with the UMCG.

In conclusion, it can be said that regionally, there have not really been any pilots started using Blockchain in real estate processes. Now that it is clear which developments of Blockchain are taking place at different levels, an image can be sketched what its influence is on the value chain of real estate.

\section{Blockchain and the Impact on the Value Chain of Real Estate}

The value chain consists of the ownership of real estate and the cash flows around it for trading. In this value chain, the cadastre, the notary, the owner, and the banks play a role. Blockchain technology can play a role in efficiency in the chain. Whether, for example, the notary or the cadastre will maintain their role in the value chain is the question. As disappointing as it was for Kodak, the company was unable to take the step from analogue to digital photography, and even the company itself had developed the technology. The real revolution in photography was outside Kodak because we started taking more pictures and sharing them with each other faster. This resulted in a different value chain than that of photo rolls, chemicals, and photo paper.

The developments of Blockchain are comparable with the rise of the Internet. Essentially, it is a global exchange of information, and the element of value exchange is now added by Blockchain. The unique thing about Bitcoin is that it counteracts spending money twice. But the true meaning of the Blockchain technology for real estate processes still needs to be investigated. Many stakeholders see the developments, as well as developments around PropTech, but still have to find their own role. It is therefore mainly about cooperation in the value chain. For this, we look at applications of PropTech, Blockchain, and data ethics in the real estate sector and the changes in it.

\section{PropTech, Blockchain, and Data Ethics}

Before we continue with Blockchain, it is also important to look further into technology in user's buildings. PropTech is a merger of Property and new Technology, and refers to technology such as the allocation of parking and workplaces to users and apps that allow a workplace to be customized to personal preferences. Users often expect higher service levels, like people expect in other sectors such as banks, healthcare, education, and so forth. An example of a high level of real estate services is zuidasoffices.amsterdam, which offers many facilities: hotels, restaurants, tailors, train times, and a selection of offices. PropTech offers advantages for increasing user's satisfaction, health, and performance. New technologies like Virtual and Mixed Reality (VR/MR), artificial intelligence, the use of IT technology in industrial systems, and PropTech (RICS, 2017) are changing how we use, 
understand, and interact with real estate. Digital transformation has an impact on the use of real estate, which should therefore be in part determinative of strategy for future-proofing, and thus determines the viability of real estate. How can Blockchain support this?

Characteristic of Blockchain is that, like money, it can be spent once. A Blockchain transaction cannot be copied and is a parallel which can thus be drawn to the real estate sector. The possibilities are in the value chain of real estate: ownership, possession, characteristics and transaction, the transfer of ownership and possession, with elements of transparency of money streams in the financial market around that. This is currently not (yet) elaborated. Blockchain technology can add value for the cadastre, notary, or broker. A few but not an exhaustive list of examples of possible concrete applications are for example (DTZ, 2016):

(1) There have been laws and regulations for Alternative Investments Fund Managers Directive for real estate fund managers for a number of years. An important issue is safeguarding assets, i.e. determination of ownership. This problem is more effectively eliminated with Blockchain;

(2) Brokers can use Blockchain technology to register ownership of objects and in case of change through sales or rental, all relevant data can be easily checked;

(3) The use of Blockchain also makes it possible to document building characteristics, such as building drawings, BIM applications, maintenance history, ownership history, and all other official documentation for a building that comes from different parties. This means that when transferring a building, all that documentation is automatically presented and transferred.

The artificial intelligence through algorithmizing of the Blockchain will increasingly play a role in the taking of decisions by learning organizations. Harari (2017) stated that the world could be subject to dataism, a data belief that every human act is a matter of the right algorithms and sufficient data processing capacity. Internationally, only limited research is currently taking place on the influence of algorithms on society and, in particular, the economy. A proposal under responsible data science in the Netherlands was rejected by the NWO (Netherlands Organisation for Scientific Research) in 2016 (Stolze, 2017). Artificial intelligence and its influence on society are not new. It originated in the 1930s with Alan Turing's Turing Machine, with which he broke the German Enigma Code and started the end of the Second World War. Science has been looking for some time for a computer that can withstand the Turning test. Another example of the great influence of algorithms is, for example, the COIN algorithm developed by JP Morgan. This is a software program that can read through thousands of contracts in a short period of time and provide an opinion instead of 300,000 hours by ordinary lawyers (Stolze, 2017). It is good to realize that (thinking) processes and decisions are being outsourced by algorithms. This artificial intelligence cannot use a combination of hard and soft factors to make considerations. The question is whether we will use the big-data models correctly and not inadvertently bring about inequality, discrimination, and reduced vigilance. That technology is developing faster than the adaptability of people is also not new: the parachute was invented only after the first plane flew. Ethics for individuals and organizations remains important for judging and deploying data well (RICS, 2007a; 2007b) because we are producing an extreme amount of data that are increasingly difficult to secure, but also more difficult to organize, archive, and keep accessible. But what are the changes in the real estate sector at the moment?

\section{Changes in the Real Estate Sector}

Looking at the activities in the Dutch real estate investment market, a quantitative analysis by the NVM (NVM, 2017b) concludes that approximately 11 billion euros were invested in real estate in the Netherlands last 
year, of which approximately 8 billion euros were in offices, commercial buildings, shops, and hotels. This investment market is driven mainly by the ample availability of capital, interest rates, economic recovery, and more leases. For foreign investors, the attractive initial yield was above all a decisive driving force. The NVM further sees that: (1) internationalization continues; (2) there is an increased interest in offices; (3) commercial spaces are popular; (4) hotels in Amsterdam are popular; (5) there is less interest in retail investments; and (6) there is great demand rental housing.

The real estate market in general is therefore constantly moving, but how can the real estate sector anticipate Blockchain? According to the Real Estate Report 2016 from the FGH Bank N.V. (2016), despite the recovery of economic growth and the greater investment willingness in the Netherlands, there still remains vacancy of about 40 million $\mathrm{m}^{2}$ for which there is not yet a solution. This applies not only to offices and shops, but also to care homes, neighbourhood centres, churches, schools, showrooms, agricultural buildings, and commercial buildings. This vacancy has arisen because we need less space to deliver the same economic performance. In addition to the excessive construction production, the overcapacity according to FGH is mainly due to the fact that the real estate sector has not adequately adapted to the changing environment. There are a number of changes in society and the economy that greatly affect the real estate sector:

(1) The number of workers and consumers does not grow automatically;

(2) Existing Dutch sectors are changing under the influence of digitalization, automation, and robotization. The (professional) population increasingly consists of "digital natives";

(3) The space usage per person is decreasing: the use of facilities is becoming more important than their ownership;

(4) Increasing internationalization of Dutch real estate users and investors.

Global developments affect the Dutch economy. Think of tensions on the world stage with wars and migrants, macroeconomic developments such as changing world trade, slowdown in growth in countries such as China, Russia, Brazil, Argentina, and South Africa and users who want flexibility in products and services. The latter demands options and customized spaces in the real estate sector. The real estate sector is also a safe haven for investors. To keep it that way, according to the FGH, the investment and user market should also be balanced in the long term. This can be achieved by being conservative about adding unnecessary real estate meters to prevent capital destruction.

The Dutch economy is strong, but vulnerable. Its strength is in exporting products and services abroad, especially food and agricultural products. This is due to the high labour productivity, digital infrastructure, and the use of smart applications. However, aging will decrease the number of workers. Therefore, it needs to compensate with higher labour productivity to stay competitive. This requires innovation. A strong competitive position is an important pillar under the basic potential of Dutch real estate.

\section{How Do We Want to House Ourselves, Live and Work in the Future}

Young generations organize their lives and work in a new way. This has consequences for the demand for space and how it is used. New generations are looking for "smart solutions" for all the issues in our society. Think of The Edge in Amsterdam, the icon of automation, or Patch 22 in Amsterdam, a smart wooden design for flexible use. The quality of the digital infrastructure and high-quality products offer more flexibility and quality for the user. Chains are more efficient and integrated and this means less time, less space, so less cost. The real estate sector therefore does not benefit from additional meters, but in strengthening existing locations 
through new construction or redevelopment, especially at the strong locations. It is not so much about the building (supply) but respond to the demand with total housing solutions. Consider the real estate as a flexible total service with, for example, flexible contracts.

\section{Conclusions}

In conclusion, the scenarios indicate a slight (2\%) to stronger (13\%) increase in demand for rental housing in 2025 compared to 2016. There will be a sustained demand for housing because housing occupancy continues to decline, starters look later for a home to purchase, and a larger part of the population is looking for flexibility and temporary housing solutions. Think of (temporary) second homes like expat houses or pied-à-terres. Only in scenario 2 is there a (slight) increase in demand for shops (2\%) and offices (7\%) in 2025 compared to 2016. This demand for space would arise as a result of productivity growth. All the other scenarios assume a decline in demand for shops and offices in 2025 compared to 2016, ranging from a decrease of $28 \%$ to $13 \%$. The demand for commercial space decreases slightly in scenarios 1,2 , and 3 by $1 \%$ to $6 \%$. The only increase in demand can be expected in scenario 4 with $2 \%$.

In short, according to the Real Estate Report 2016 (FGH), there is a high probability that the vacancy in the existing supply of offices, shops, commercial spaces, and social real estate will be permanent. It is therefore about real estate entrepreneurship. National control over the total vacancy is desirable. Long-term trends and developments per real estate sector are for:

(1) Offices market: in the long term, there is supply reduction and greening of the (existing) supply needed to improve the value perspective. The demand for offices will go up, and the supply will go down due to withdrawal from the market and more office investments (NVM, 2017b);

(2) Retail market: total retail usage shrinks in the longer term (2025) by possibly $25 \%$. Retail locations with unique qualities and a high service area become more attractive as an investment with good prospects (NVM, 2017c; Dynamis, 2016a);

(3) Commercial space market: an increasing demand for commercial space in logistics and modern production. Usage (and service life) of commercial space becomes more flexible; the average service life decreases and thus the payback time (Dynamis, 2016a; 2016b);

(4) Rental housing market: the value perspective of rental housing is favourable in the short and medium term, due to more demand than supply with prospects for the middle segment (PBL, 2017). There is no bubble in the housing market in the big cities at this time. Due to the overheating in the big cities, families mainly relocate to neighbouring municipalities looking for affordable homes. The housing market then accelerates there. People in the rest of the country move away. The housing market there remains in a slump (De Nederlandsche Bank, 2017);

(5) Investment real estate market: differences between initial returns for good-quality property and other real estate continue to increase. Expectations are that the investment market will now be more successful and will remain dynamic (NVM, 2017a);

(6) Real estate financing market: banks are increasingly the financial directors between real estate investors and investors. There seems to be momentum for further expansion of the real estate financing portfolio (Syntrus Achmea, 2017);

(7) Logistics real estate market: the research of Savills (van Oers, Poppelaars, \& Jansen, 2017) gives three key trends that will be determinative in 2017 for the logistics real estate market: (a) the extent of new logistics 
developments continues to increase. Ten years ago, an average new development was $16,900 \mathrm{~m}^{2}$; now it is over $28,850 \mathrm{~m}^{2}$. The demand for new distribution centres is not yet declining, and Savills also expects more of such XL developments in 2017; (b) the growth of e-commerce. Online spending grew by $18.7 \%$ in 2016 compared with the previous year. In order to be able to further facilitate this growth, the supply chain must be modernized and optimized; and (c) political and economic uncertainty;

(8) Social real estate market: the Barometer for Social Real Estate 2017 (Veuger, 2017) gives clear insights into future issues regarding social property.

\section{Real Estate and Blockchain Internationally: First Pilots and in Silence}

The cadastre is currently exploring internationally the possibilities of Blockchain, where various movements can be observed. Some countries like Georgia and Sweden are actually testing with Blockchain. Estonia and Dubai are also running pilots, but doing so in silence. Countries like Ghana, Georgia (US), and Brazil have different ideas, but have not (yet) worked these out (Vos, Beentjes, \& Lemmen, 2017). The Bitfury Group is currently working on a number of studies in Georgia (US). The government in Honduras has started a project to register land that has not yet led to results and publications and recently stopped (Drucker, 2016). Within the cadastre, an international expert team is working on further exploration. In conclusion, Vos et al. (2017) stated that Blockchain is not yet proven in practice internationally and that completeness and transparency are the conditions for being able to make Blockchain a success.

In Sweden (Salmeling \& Fransson, 2017), a test environment has been built as part of the Land Registry project in the Blockchain to understand Blockchain's technology, processes, and security issues that need to be considered and given legal form. The Blockchain tested here for real estate is implemented by a group of public and private entities. In this test environment, it has been found that six features are important for a safe process (Salmeling \& Fransson, 2017, pp. 4-5). The next steps they will take concern the technical environment, technology and process integration, more partners and projects, legal conditions and lobbying, and ownership and control. The value of possible Blockchain solutions for real estate lies mainly in a more effective and more efficient method of transactions, a better foundation for better investment and new development for the mortgage market. All this will then grow into more trust in fundamental parts of an economy: land and real estate.

\section{Real Estate and Blockchain Nationally: Digital Solutions}

At the national level, there are a number of Blockchain pilots with real estate: (1) open data from the cadastre; (2) government-wide pilot on the possibilities for processes; and (3) a pilot by the Living Environment and Transportation Inspectorate (ILT). For the government-wide pilots, primarily the processes of real estate, aviation and ships are being investigated, in which the process of registration of ships in the Blockchain is now being investigated (Vos et al., 2017).

In the Netherlands, Blandlord crowd ownership has been introduced and is utilizing Blockchain. The ownership of the real estate is then divided among a number of owners and fits into the philosophy of a sharing economy: a group of equals collectively take responsibility for the property without debt or mortgages. No public information is available yet about the results to date.

Deloitte (2017d) ${ }^{11}$ explored eight trends that will have a major impact on the real estate industry. In random order:

\footnotetext{
${ }^{11}$ Source: https://www2.deloitte.com/content/dam/Deloitte/nl/Documents/real-estate/deloitte-nl-real-estate-the-future-of-commer cial-real-estate-in-europe.pdf.
} 
(1) Cyber risk: smart buildings are increasingly an important competitive advantage and can even generate new revenue. However, the emergence of these "smart buildings" also brings along points of attention, including cyber risks.

(2) Crowdsourcing: crowdsourcing is on the rise. More and more companies are seeing opportunities in utilizing the knowledge, expertise, or creativity of a large group of people online. This method allows for a more flexible workforce and, consequently, a flexible shell of office space.

(3) Smart mobility: when travellers can use their travel time fully productively, for example with self-driving cars, what will this mean for housing prices, for example? This is now often based on location, but what if location does not matter?

(4) Future of work: the changing jobs are not only coming from organizations; employees also have different expectations of their employer.

(5) Blockchain 2.0: Blockchain offers enormous opportunities, and the real estate industry is increasingly experimenting with this distributed trust.

(6) Standardization: we expect more collaboration in the future on sharing and exchanging data. These data partnerships offer a lot of added value.

(7) Ports: Three major topics will (have to) receive a lot of attention from the maritime sector in the coming period: smart ports, increasing cooperation between seaports, and new niches (at the expense of fossil fuels).

(8) Smart cities: increasingly, digital technologies will be used to solve urban challenges.

\section{Real Estate and Blockchain Regionally: Groningen as a Flywheel}

With the aforementioned developments, there are also many possibilities to investigate disruption, Blockchain, and real estate and to collaborate on the four themes of the Research Centre for Built Environment NoorderRuimte: Shrinkage, Earthquakes, Health \& Wellness, and Sustainability \& Abundance (Veuger, Meier, Mobach, Oostra, \& Stijnenbosch, 2015). But what are the issues on those four themes related to disruption, Blockchain, and real estate?

Shrinkage and the city on the rise. Shrinkage in the region and growth in the city of Groningen are two often-discussed issues in the region and not significantly different from the Randstad compared to the surrounding area (Meier, Reverda, \& van der Wouw, 2015). In addition to vacancies, there is also room for renewal and change. Space also gives new insights because perspectives are changing. According to Bock and Bulder (2017), two perspectives are particularly interesting: (1) the connection between social and spatial inequality; and (2) the meaning of increasing mobility. The research that Bock will do in the coming years is about understanding the origin and identifying shrinkage and anticipation regions that form part of the process of spatial inequality between central areas of the cities Leeuwarden and Groningen and the periphery. Real estate plays an important role in that because users of facilities do not have municipal boundaries (Meier \& Bovenhoff, 2014) and accessibility is more determinative of use than the immediate proximity of facilities.

The fact that there are differences between the city and the countryside is not new and often less great than imagined. The Central Planning Bureau (CPB) (Steenbekkers, Vermeij, \& van Houwelingen, 2017) notes that known contrasts between cities and countryside with different types of villages have not been systematically different in recent years. With this, differences have not increased and so the existing gap has not changed. The liveability in shrinkage regions decreases because facilities disappear, but residents do not evaluate this change as 
negative, according to the $\mathrm{CPB}$ investigations. This conclusion is in line with previous conclusions from the study of the housing market and liveability study of the Groningen earthquake area by Boelhouwer et al. (2016). None of this alleviates the vulnerable position of the villages and their inhabitants. According to the $\mathrm{CPB}$, it is important to reflect on the changing circumstances and the action perspective that can be anticipated:

(1) If it turns out that liveability and self-reliance fall short, then it is sensible and necessary to establish and utilize connections between the region and the city, and to manage on a revision of the regional economic policy.

(2) It is good to think about technologies that can change the structure of society, and thus the city and the region. Increasing independence of time and place is among the possibilities for further investigation.

(3) New forms and sources of social cohesion can provide another route to achieving the necessary transition of society. Space in the region and knowledge from the city can provide cohesion and tension. Preconditions from the government can guide the transition and ensure that spatial values are a source rather than a struggle.

Lines to guiding transition are also specified by the lectorate of Shrinkage \& Living Environment (Bulder, 2017), activities are identified, and projects are rolled out with stakeholders. The Knowledge Agenda Knowledge Network Noord-Nederland 2017 developed by Bock and Bulder (2017), which is built around the themes of liveability and healthcare, economic vitality, the city-countryside relationship, and spatial inequality is complementary to applied scientific research.

The three Northern provinces, the Ministry of Economic Affairs, and the municipalities of Assen, Emmen, Groningen, and Leeuwarden aim to increase the competitiveness of Northern Netherlands by intervening in the living environment (Zwarte Hond, 2017). They have three main tasks: (1) strengthening economic structure; (2) strengthening environmental qualities; and (3) better connecting the Northern Netherlands. Groningen in particular is growing quickly due to the fact that in 2019, Ten Boer and Meerstad will be added to Groningen, which will make Groningen the 5th largest city in the Netherlands with a future of an estimated 250,000 inhabitants. Groningen is working on the issue of where it wants to be as a city in 2030 (The Next City. Hoe zie je de stad?), what choices should be made in this context and what the impact is on real estate in the city. In the recommendation from the SER $(2015)^{12}$, a desire has already been indicated to ensure as much as possible that people contribute to and benefit from the success of the city of Groningen, the development and utilization of talent and that entrepreneurship must be central. Cooperation between all stakeholders in the region is then essential. Administrative alignment and management are required to prevent things from becoming disjointed (Veuger, 2016) and Blockchain will be able to be supportive in that in particular.

Earthquakes, value decrease, and compensation. On January 21, 2015, the National Coordinator Groningen (NCG), Hans Alders, received the final conclusions and opinions from the Housing Market Research from the steering committee Housing Market of the Dialogue Board. The Housing Market Research is a broad survey of various aspects of the housing market. Based on the results, the steering committee advises the NCG, inter alia, to maintain the existing value increase scheme, to provide more security for residents and owners who want to sell their homes, and to apply a more generic purchase arrangement.

The population shrinkage and earthquakes have led to the loss of normal function of the home sales market in the earthquake area. Especially, the combination of shrinkage and earthquakes is a poisonous cocktail for the future. The restoration of the home sales market in the earthquake area lags behind the rest of the province of

12 Source: https://www.ser.nl/nl/publicaties/adviezen/2010-2019/2015/ser-agenda-stad.aspx. 
Groningen (excluding the Municipality of Groningen) and in the Netherlands. This is evidenced by the number of homes for sale, based on the development of the number of homes sold, the selling price, the sales time, the difference between the transaction price and the asking price, the number of homes for sale and the average maturity of the properties available for sale. In the NCG's plan, the purchase scheme limits itself to those homes whose security cannot be guaranteed fast enough or where the cost of damage repair and/or reinforcement is greater than the economic value. In addition, purchases can also be made in urgent situations. The researchers advise an expansion of this purchase scheme to all cases where residents cannot sell their property within a reasonable time for a reasonable price. In the case of a purchase scheme, it can best be connected to the "Moerdijk scheme", where the home value of an individual home is calculated by indexing the WOZ value from the past to the present time. The uncertainty about the value of the house is an importantly negative effect of the earthquake problem. At present, any compensation for value decrease is determined only after sale. For a good value-compensation scheme, it is important that it will be simple and transparent, allowing residents to estimate in advance how much compensation for loss of value they are entitled to (Hanssen, Top, \& Veuger, 2015). Blockchain would have added value here in the sense of transparency and trust in the present and future of valuation and monitoring of earthquakes across the full breadth.

Sustainability and integrated transition. In the transition to an energy-neutral built environment, Rotmans (2017) stated:

The intention is that our country will be energy-neutral in 2030. If you then realize that households are responsible for about fifty percent of the $\mathrm{CO}_{2}$ emissions, you must make all seven million homes energy neutral. That is hundreds of thousands of homes per year. In the Stroomversnelling, 2,000 NOM homes (Investment and development agency for Noord-Nederland) have been realized in five years' time, half of which are existing buildings. With their more than 2 million homes, housing corporations still have a good way to go. I regularly host groups of housing corporations and hear two things. Of course, you can keep on waiting on new technology resistance; then a group of leaders form and the resistance gradually decreases and then the big break-through comes.

According to Rotmans (2017), Groningen could see a major breakthrough as a flywheel, where 100,000 households are struggling with the consequences of the earthquakes resulting from gas extraction by the NAM:

Reinforcing and immediately making 100,000 homes there energy neutral could be a flywheel for the rest of the Netherlands. There is urgency and money, making it attractive for pension funds and housing corporations to invest in the energy neutralization of the built environment. A salient detail is that Groningen can be a leader when it comes to making the Netherlands free of natural gas. In addition, the project in Groningen creates an estimated 150,000 new jobs. It is up to the new cabinet whether they will make a national virtue of Groningen's emergency.

Rotmans' agenda (2017) consists of four key themes: (1) making the built environment energy neutral, and in time, energy-generating; (2) making homes digital and smart (within 10 years, homes will manage us: by using sensors, the Internet of things, and big data, homes will always be "connected"); (3) a circular or recirculating economy, where you use instead of owning; and (4) making homes lifespan proof so you can serve multiple target groups with the same property. The most ideal thing is to address these four agenda items in coherence, depending on the different situations in the built environment, in which Blockchain supports the decision-taking processes.

Healthy ageing. At the end of 2016, the Healthy Ageing Vision (2017) for the city of Groningen was presented. The city, partners in the Groningen Accord, and Healthy Ageing Network Northern Netherlands (HANNN) are a catalyst for more intensive cooperation around the Healthy City. They organized the 
conference "Building the Future of Health" in 2016, an international conference on the impact of the physical living environment on health (Veuger, 2016). After this conference, the partners decided to anchor the most important insights in the city in the form of an integrated approach to the city of Groningen as a Healthy City. This was reflected in the Healthy Ageing Vision. This vision forms, for the long term, the common perspective of the city and has six guidelines (G6) that will serve as a guide: Active Citizenship, Accessible Green, Active Relaxation, Active Movement, Healthy Building, and Healthy Food. The guidelines are also anchored in municipal policy programs such as the health policy "Healthy Together in the City" and the new ones "Environmental Vision", "The Next City". With the G6 as a starting point and keystone for all multi-year programmes, policy developments, and projects of the city of Groningen, they want to make the policy programmes Healthy Ageing proof. Outsourcing of processes, data analyses, and hard facts by Blockchain combined with soft factors like circumstances and compassion can support directors in taking decisions.

\section{Conclusions: Trust in a Viable Real Estate Economy}

The way in which disruption, Blockchain, and real estate will develop in the coming years is not the only obvious characteristic of a particular era, but also its social impact and user behaviour. This also applies to how this real estate transition can best be tracked, guided, and utilized in society at the international, national, and regional level. Disruptive organizations clearly respond to the viability of the (built) environment and therefore determine competitive strength. This affects the current and future valuation of real estate. The value of the possible applications of Blockchain in real estate processes is reflected in more effective and efficient transactions, increasing transparency, a better foundation for investment, and new development for the mortgage market. All of this will then grow into more trust in fundamental elements of an economy: land and real estate and from the "Internet of things" to an "economy of things".

Looking at the impact of Blockchain on real estate, we can draw a number of conclusions. First of all, the relationship between Blockchain and real estate has not yet been proven in practice. It is expected to develop further in the form of registering transaction processes and the DNA passport of a real estate object. Secondly, completeness and transparency are the basic ingredients for trust in the system. Thirdly, real estate wants to remain viable. For this reason, taking the offense is necessary for real estate and management to connect with social demand. Behaviour also leads to new earnings models of the social and economic spin-off of disruptive real estate. If the Dutch real estate sector embraces Blockchain and is able to realize innovations, then there are opportunities for real estate entrepreneurs to exploit the disruptive character to provide those new services.

Artificial intelligence through algorithmizing of Blockchain will increasingly play a role in the taking of decisions by learning organizations. It is good to realize that (thinking) processes and decisions are being outsourced by algorithms. This artificial intelligence cannot combine hard and soft factors to make considerations. The question is whether we will use the big-data models correctly and not inadvertently bring about inequality, discrimination, and less vigilance. That technology develops faster than the adaptability of people is also not new: the parachute was invented only after the first plane flew. Ethics for individuals and organizations remains important for judging and utilizing data.

Changes in value concepts affect the valuation of real estate and the thinking about it. The orientation of changing users and owners of real estate affects innovativeness, values, and flexibility in managing that property. Orientation on disruption must be seen as proof that the real estate world is able to actually innovate the accumulated assets and consolidate this. The financial and real estate markets are markets that exaggerate 
through irrational behaviour. Fear of "eat or be eaten" determines people's behaviour. Financial and thus real estate markets are always unstable and must always be regulated by people and organizations.

The question that remains is whether it is important to look at disruptive innovations in existing markets or newcomers in the real estate market and Blockchain. The question is whether Blockchain is only a technological disruption, or a real game changer, and whether the entire value chain of the real estate market will embrace it. No two disruptions are the same. Trust in Blockchain is a prerequisite for guiding the predictable form of that disruption where start-up companies use new technology to offer cheaper and inferior alternatives to real estate in the market. You could also talk about antifragile value:

Some things benefit from shocks; they thrive and grow when exposed to volatility, randomness, disorder, and stressors and love adventure, risk, and uncertainty. Yet, in spite of the ubiquity of the phenomenon, there is no word for the exact opposite of fragile. Let us call it antifragile. (Taleb, 2012)

In other words, attention to disruption and Blockchain creates a viable real estate economy.

The true meaning of the Blockchain technology for real estate still needs to be investigated. The author is still curious to understand and clarify the value of Blockchain for real estate processes. Doubt continues to exist and is therefore a feeding ground for further research, because we do not know what we have not seen.

\section{References}

Aris, A. (2015). Waarom disruptie niet altijd disruptie is (Why disruption is not always disruption). Rotterdam: Het Financieele Dagblad.

Bakker, S. (2017). Niet de technologieën maar het gedrag. Omslagverhaal De Ware disruptie (Not the technologies but the behaviour. Conversion story the real disruption). Rotterdam: Het Financieele Dagblad.

Bikker, A. (2016). Blockchain pilot in commercial real estate. Amsterdam: ABN AMRO. Retrieved from https://www.abnamro. com/en/newsroom/press-releases/2016/Blockchain-pilot-in-commercial-real-estate.html

Bock, B. B., \& Bulder, E. A. M. (2017). Kennisagenda Kennisnetwerk Krimp Noord Nederland 2017 (Knowledge agenda knowledge network shrinkage in Noord Nederland). Groningen: Rijksuniversiteit Groningen en Hanzehogeschool Groningen.

Boelhouwer, P., Boumeester, H., Groetelaers, D., Hoekstra, J., van der Heijden, H., Jansen, S., ... Ringersma, R. (2016). Woningmarkt- en leefbaarheidsonderzoek aardbevingsgebied Groningen (Housing market and liveability research in the Groningen earthquake area). Delft (TU Delft—OTB Onderzoek voor de gebouwde Omgeving). Retrieved from https://www.rijksoverheid.nl/documenten/rapporten/2016/01/26/woningmarkt-en-leefbaarheidsonderzoek-aardbevingsgebied -groningen

Bulder, E. A. M. (2017). Responsieve regio. Pionieren met demografische transitie van Noord-Nederland (Responsive region. Pioneering with the demographic transition of Noord-Nederland). Groningen: Hanzehogeschool Groningen, Kenniscentrum NoorderRuimte.

Camu, K. (2017a). De toepassing van Blockchain is belangrijker dan de technologie (The application of Blockchain is more important than the technology). Zandvoort: Vastgoed Journaal.

Camu, K. (2017b). Nationale Blockchain wil Nederland voorloper maken (National Blockchain wants to make the Netherlands the leader). Zandvoort: Vastgoed Journaal.

Christensen, C. M., \& Bower, J. L. (1995). Disruptive technologies: Catching the wave. US: Harvard Business Review.

Christensen, C. M., Raynor, M. E., \& McDonald, R. (2015). What is disruptive innovation? US: Harvard Business Review.

de Kam, G. (2016). Waarde Groningse huizen daalt met 1 miljard euro door aardbevingen (Value of Groningen houses falls by 1 billion euros due to earthquakes). Retrieved from http:/www.rug.nl/news-and-events/news/archief2016/nieuws berichten/waarde-groningse-huizen-daalt-met-1-miljard-euro-door-aardbevingen

De Nederlandsche Bank. (2017). DNB: de woningmarkt on de grotesteden (DNB: The housing market in the big cities). Amsterdam: De Nederlandsche Bank N.V.

Deloitte. (2017a). Blockchain en real Estate event \& demo. De toekomst begint vandaag. 18 mei 2017 (Blockchain and real estate event \& demo. The future starts today. 18 May, 2017). Rotterdam: Deloitte, Municipality of Rotterdam and CIC. 
Deloitte. (2017b). Real estate predictions 2017. What changes lie ahead? Amsterdam: Deloitte.

Deloitte. (2017c). Smart and connected real estate event, May 23, Rotterdam. Rotterdam: Deloitte.

Deloitte. (2017d). The future of commercial real estate in Europe. A scenario approach. Amsterdam: Deloitte.

Dijkgraaf, R. H. (2017). De wereld is meer verstrengeld dan we denken (The world is more entangled than we think). Interview in Het Financieele Dagblad, 29-30 April, 2017, pp. 17-18. Rotterdam: Het Financieele Dagblad.

Dijkstra, M. (2017). Blockchain: Towards disruption in the real estate sector. An exploration on the impact of Blockchain technology in the real estate management process. Delft: University of Delft.

Drucker, P. (2016). Blockchain applications in the public sector. London, United Kingdom: Deloitte.

DTZ. (2016). Blockchain: innovatie in Vastgoed (Blockchain: Innovation in real estate). Retrieved from http://www.duidelijkdtz. nl/optimaliseren/Blockchain-innovatie-in-vastgoed/

Dutch Blockchain Coalition. (2017). Actieagenda Nationale Blockchain Coalitie (Action agenda of the national Blockchain coalition).

Dutch Digital Delta. (2017a). Knowledge and innovation agenda ICT 2016-2019. Retrieved from https://www.dutchdigitaldelta. nl/uploads/pdf/PDF-Kennis-en-Innovatieagenda-ICT-2016- 2019_2015-10-06_254.pdf

Dutch Digital Delta. (2017b). Legacy Coalitie (Legacy coalition). Retrieved from https://www.dutchdigitaldelta.nl/uploads/ pdf/ddd-Legacy-Flyer.pdf

Dynamis. (2016a). Speekende cijfers winkelmarkt (Key figures from the retail market). Utrecht: Dynamis B.V. Research Department.

Dynamis. (2016b). Sprekende cijfers Bedrijfsruimten (Key figures for commercial spaces). Utrecht: Dynamis B.V. Research Department.

FGH Bank N.V. (2016). Vooruitzien en veranderen (Anticipating and changing). Vastgoedbericht 2016. Utrecht: FGH Bank N.V.

FGH Bank N.V. (2017). Vastgoedbericht 2017. Bricks en bytes smelten samen (Bricks and bytes melting together). Utrecht: FGH Bank N.V.

Gehl, J. (2010). Cities for people. Washington, D.C.: Island Press.

Gout, B. (2017). Block mortgage: Blockchain inspired business model for mortgage funding marketplace. Delft: Delft University.

Hanssen, H., Top, S., \& Veuger, J. (2015). Groningse leefbaarheid en woningmarkt zwaar onder druk. Het woningmarkt- en leefbaarheidsonderzoek aardbevingsgebied Groningen (Groningen liveability and housing market under intense pressure. The housing market and liveability research in the Groningen earthquake area). In J. Veuger, A. van den Beemt, E. de Klerk, D. Kootstra, and C. L. A. Worms (Eds.), Barometer Maatschappelijk Vastgoed (Barometer for Social Real Estate) (pp. 447-450).

Harari, Y. N. (2017). Homo Deus. Een kleine geschiedenis van de toekomst (Homo Deus. A brief history of the future). Amsterdam: Thomas Rap.

Hartholt, S. (2017). Blockchain onder de loep bij overheden (Blockchain being examined by governments). Amsterdam: Binnenlands Bestuur.

Healthy Ageing Visie. (2017). De G6 voor een Gezonde Stad Groningen. Concept (The G6 for a healthy city of Groningen. Concept). Groningen: Municipality of Groningen.

Het Financieele Dagblad. (2017a). Ook het kadaster experimenteert met Blockchain (The cadastre is also experimenting with Blockchain). Rotterdam: Het Financieele Dagblad.

Het Financieele Dagblad. (2017b). Opbouw van kennis Blockchain in Nederland is in de maak (Building knowledge of Blockchain in the Netherlands is underway). Rotterdam: Het Financieele Dagblad.

IBREA. (2017). Blockchain meets real estate. 11 July, 2017. Amsterdam: IBREA and ABN AMRO.

KPMG. (2016). Missing link. Navigating the disruption of Blockchain. USA: KPMG LLP.

Lifthrasir, R. (2016). Chain reaction. RICS property Journal.

Lifthrasir, R. (2017). Blockchain platforms: Speeding up the money \& assets transfer process. RICS Land Journal. Retrieved from http://www.rics.org/nl/news/het-latest-nieuws/comment/chain-reaction/

Meier, S., \& Bovenhoff, M. (2014). Gebruikspatronen in beeld: hoe benutten en waarderen inwoners van Slochteren de maatschappelijke voorzieningen? Deelrapportage I van "Maatschappelijke voorzieningen in de gemeente Slochteren" (A view of usage patterns: How do residents of Slochteren use and evaluate the social facilities? Partial report I from "social facilities in the Municipality of Slochteren"). Groningen: NoorderRuimte, Research Centre for Built Environment, Hanze University of Applied Sciences, Groningen.

Meier, S., Reverda, N., \& van der Wouw, D. (2015). Randland (Around the Randstad). Amsterdam: Faculteit der maatschappij en gedragswetenschappen, afdeling geografie, planologie en internationale ontwikkelingsstudies of the University of Amsterdam. 
NVM. (2017a). Beleggen in Nederlands Vastgoed (Investing in Dutch real estate). Nieuwegein: NVM.

NVM. (2017b). Kantorenmarkt Randstad 2016. Een stand van zaken (Offices market in the Randstad 2016. A state of affairs). Nieuwegein: NVM.

NVM. (2017c). Nederlandse Winkelmarkt. Stand van zaken (Dutch retail market. State of affairs). Nieuwegein: NVM.

NVM. (2017d). NVM Business Innovatiecongres 18 april 2017 (NVM Business Innovation Conference 18 April 2017). Nieuwegein: NVM. Retrieved from https://proof.medialab.co/share/email/oaw3eK/cb7ee5154e939223ac6a9ddce36e77 ffc80ef 7e4588ba1007838ee9915192026\#

PBL. (2017). Perspectieven voor het middensegment van de woningmarkt. Verkenning van maatregelen ter bevordering van het aanbod (Perspectives for the middle segment of the housing market. Exploring measures to promote the supply). Den Haag: Planbureau voor de leefomgeving.

Pouwelse. (2017). Onderzoek Blockchain envastgoed (Research on blockchain and real estate).

Real Estate Journal. (2017). De toepassing van Blockchain is belangrijkerdan de techonologie (The application of Blockchain is more important than technology).

RICS. (2007a). Rules of conducts for firms. Version 5 with effects from 1 January, 2012. United Kingdom: RICS.

RICS. (2007b). Rules of conduct for members. Version 6 with effects from 1 January, 2013. United Kingdom: RICS.

RICS. (2017). De opkomst en groei van Proptech (The rise and growth of PropTech). Voorburg: RICS.

Rotmans, J. (2013). In het oog van de orkaan. Nederland in transitie (In the eye of the storm. The Netherlands in transition). Boxtel: Aeneas.

Rotmans, J. (2017). Groningen als vliegwiel voor een energieneutraal Nederland (Groningen as a flywheel for an energy-neutral Netherlands). Breda: CorporatieMedia.

Salmeling, M., \& Fransson, C. (2017). The land registry in the Blockchain-Testbed. A development project with Lantmäteriet, Landshypotek Bank, SBAB, Telia company, ChromaWay and Kairos Future. Stockholm: Landshypotek Bank.

Seibold, S., \& Samman, G. (2016). Consensus immutable agreement for the Internet of value. USA: KPMG LLP.

Sfirtsis, T., \& Broekman, J. (2016). Waardepatronen (Value patterns). Presentatie Provada 2016. Amsterdam: Amsterdam School of Real Estate.

Spielman, A. (2016). Blockchain: Digitally rebuilding the real estate industry. Cambrigde, Massachusetts: Massachusetts Institute of Technology.

Steenbekkers, A., Vermeij, L., \& van Houwelingen, P. (2017). Dorpsleven tussen stad en land. Slotpublicatie Sociale Staat van het Platteland (Village life between city and land. Closing publication of the social state of the countryside). Den Haag: Sociaal en Cultureel Planbureau.

Stolze, J. (2017). Blijf niet steken in digitalisering (Do not get stuck on digitalization). Essay in Het Financieele Dagblad.

Syntrus Achmea. (2017). Outlook 2017-2019. Beleggen in Nederlands Vastgoed en hypotheken (Outlook 2017-2019. Investing in Dutch real estate and mortgages). Amsterdam: Syntrus Achmea.

Taleb, N. N. (2012). Antifragile: Things that gain from disorder. New York: Random House Trade Paperback Edition.

van Bentum, J. (2017). Businessmodel bepaalt waarde, niet langer het huurcontract (Business model determines value, not the rental contract anymore). Amsterdam: Vastgoedmarkt.

van Oers, D., Poppelaars, N., \& Jansen, J. (2017). Logistics market update. Further yield compression driving (speculative) developments. Amsterdam: Savallis World Research.

van Os, A. (2016). Doorpakken met Blockchain (Moving ahead with Blockchain). Amsterdam: ABN AMRO BANK NV. Retrieved from https://www.abnamro.com/nl/newsroom/blogs/arjan-van-os/2016/doorpakken-met-Blockchain.html

Vastgoed Journaal. (2017). Amsterdams bedrijf komt met eerste concrete juridische Blockchain toepassing (Amsterdam company comes up with the first concrete legal Blockchain application). Zandvoort: Vastgoed Journaal.

Vastgoedmarkt. (2017). Vastgoedmarkt Trends Congres 2017 (Real Estate Market Trends Conference 2017). Amsterdam: Vastgoedmarkt, ABN-AMRO, AM, Bouwinvest.

Vermeend, S., \& Smit, P. (2017). Blockchain de technologie die de wereld radicaal verandert (Blockchain, the technology that is radically changing the world). Den Haag: Einstein Books.

Veuger, J. (2013). Denken in waarden (Thinking in terms of values). Lectorale rede. Groningen: Lectoraat Maatschappelijk Vastgoed, Kenniscentrum NoorderRuimte Hanzehogeschool Groningen.

Veuger, J. (2014). Materieel Immaterieel. Besturing van woningcorporaties in samenhang met maatschappelijke waarden (Material immaterial. Managing housing corporations in line with social values). Thesis. Rotterdam: RSM Erasmus Universiteit Rotterdam. Assen: Van Gorcum. 
Veuger, J. (2016). Krimp vraagt provinciale regie (Shrink age demands provincial governance). Interview in Leeuwarder Courant, p. 16.

Veuger, J. (2017). Barometer Maatschappelijk Vastgoed 2017 (Barometer for Social Real Estate 2017). Groningen: lectoraat Maatschappelijk Vastgoed Kenniscentrum NoorderRuimte Hanzehogeschool Groningen.

Veuger, J., Meier, S. O., Mobach, M. P., Oostra, M. A. R., \& Stijnenbosch, M. H. (2015). Position Paper NoorderRuimte 2020, Centre of Research \& Innovation for Built Environment. Lectoraten Facility Management, Krimp en Leefomgeving, Maatschappelijk Vastgoed, Ruimtelijke Transformatie en Vastgoed. Thematieken: Aardbevingen, Krimp, Duurzaamheid, Gezondheid \& Welzijn. Opleidingen: Architectuur, Bouwkunde \& Civiele Techniek, Vastgoed \& Makelaardij, Human Technology en Facility Management. Groningen, Hanzehogeschool Groningen, Kenniscentrum NoorderRuimte.

Vos, J., Beentjes, B., \& Lemmen, C. (2017). Blockchain based land administration feasible, illusory or a panacea? Netherlands Cadastre, Land Registry and Mapping Agency. Paper prepared for presentation at the 2017 World Bank Conference on Land and Povertry. The World Bank, Washington, D.C., March 20-24, 2017.

Wessels, P. (2016). Blockchain zal enorme impact hebben op vastgoedsector (Blockchain will have an enormous impact on the real estate sector). Amsterdam: Property NL.

Yermack, D. L. (2017). Blockchain is meer dan een modegril (Blockchain is more than a passing trend). Interview in Elsevier, nummet 73, 73e jaargang, p. 97.

Zaal, R. (2017). TU-Delft heeft Blockchain-hypotheek werkend (TU Delft has Blockchain mortgage working). Retrieved from $\mathrm{http}: / /$ agconnect.nl/artikel/tu-delft-heeft-Blockchain-hypotheek-werkend

Zuidam, R. (2016). Government as a service. Whitepaper.

Zwarte Hond. (2017). Sterk Noord-Nederland. Vergroten concurrentiekracht door ingrepen in de leefomgeving (Strong Noord-Nederland. Increasing competitive strength by intervening in the living environment). Groningen: Provinces of Drenthe, Friesland, Groningen, the Ministry of Economic Affairs and the Municipalities of Assen, Emmen, Groningen and Leeuwarden. 